\title{
Religiosity in Therapeutic Communication of Islamic Medicine Thibbun Nabawi
}

\author{
Tina Rakhmatin Sabariah Usman, \\ Deddy Mulyana, \\ Purwanti Hadisiswi, \\ Susie Perbawasri \\ Fakultas Ilmu Komunikasi \\ Universitas Padjadjaran \\ Fakultas Ilmu Sosial dan Ilmu Politik \\ Universitas Komputer Indonesia \\ Bandung, Indonesia \\ tina.rakhmatin@email.unikom.ac.id
}

\begin{abstract}
The purpose of this study was to determine how the religiosity of thibbun nabawi therapists in the therapeutic communication process to their patients and to determine the religiosity functions of thibbun nabawi therapists in the therapeutic communication process. Thibbun nabawi is a medical treatment rooted in the Islamic tradition because it is mentioned in the hadiths of the Prophet Muhammad. This study uses a qualitative approach with phenomenological method. The subjects of this research are therapists who works in cupping clinics in Bandung city, Indonesia. The study was conducted with interviews, observation, and document study. The results of this study indicate that when doing therapeutic communication, thibbun nabawi therapists have dimensions in the form of: (1) the belief that God is the only healer, (2) submission through prayer, (3) inner tranquility, (4) patience, (5) adherence to the Shari'a, (6) understanding of treatment methods based on the hadith of the Prophet Muhammad, and (7) the ability to convey religious messages to patients. These dimensions of religiosity are inherent in the therapist which are then shown in verbal and nonverbal messages during therapy. The functions of the religiosity of thibbun nabawi therapists in the therapeutic communication process are: (1) provoding comfort to the patient, (2) giving positive suggestion to the patient, and (3) increase credibility to the therapists. This religiosity is important to be owned by thibbun nabawi therapists because it will affect the achievement of therapeutic communication goals, namely helping to achieve recovery, spiritual (ruhiyah) strengthening, and mental strengthening of patients.
\end{abstract}

Keywords—religiosity, therapeutic communication, thibbun nabawi, therapist

\section{INTRODUCTION}

The religiosity of the therapist has an important role in the process of therapeutic communication used in the treatment of thibbun nabawi. Religiosity is defined as devotion to religion and a form of piety. Religiosity, according to reference $[1,2]$ has five dimensions, namely: belief (ideological), religious rituals (ritualistic), experience (experential), religious knowledge (intellectual), and practice. The dimensions of belief contains expectations and a set of beliefs that are held firmly to a particular theological paradigm and recognize the truth of these doctrines. The dimensions of religious rituals include a set of rituals, formal religious acts and sacred practices practiced by their adherents. The dimension of experience contains religious experiences, feelings, perceptions, sensations experienced by a person in transcendental communication with God. The dimensions of religious knowledge include knowledge of the basics of beliefs, rites, scriptures, and traditions. The dimension of practice refers to the identification of the consequences of one's religion, practice, experience, and knowledge from day to day [2].

The strong attachment between the practice of thibbun nabawi and the religion of Islam can be seen from the foundation of the knowledge and practice of the thibbun nabawi which is derived from the hadiths of the Prophet Muhammad-which contains the words, actions, behaviors, or instructions of the Prophet Muhammad - regarding health and the methods of treatment practiced by himself or recommended to his people. Faith, belief, and firmness in the hadiths of the Prophet are one of the important dimensions of the religiosity indicator of a thibbun nabawi therapist

Thibbun nabawi in general means doing treatment in the way of the Prophet Muhammad [3]. Thibbun nabawi as an Islamic medical treatment began to be known in Indonesia since the 2000s and continues to grow until now. The most popular treatment of thibbun nabawi is cupping (al-hijamah). Cupping is a treatment by removing blood from certain points of the patient's body by using a kind of cup or glass lying face down on the surface of the skin. Nowadays, urban muslim community in Indonesian can easily find cupping clinics. Information about thibbun nabawi is easy to find, especially after the massive use of internet for information search.

The main references of the practitioners of thibbun nabawi are the hadiths collected in the book Sahih Bukhari Muslim, which were then collected specifically by Imam Ibn Qayyim Al-Jauziyah (1282-1372 AD) in the book titled Za'dul Maad, 4th volume, and entitled Ath-Thibb AnNabawiy, or abbreviated as thibbun nabawi. In the book, there are hundreds of hadiths and verses that discuss the various methods of thibbun nabawi, which are grouped into 4 
main topics: the Prophet's instructions regarding treatment with natural medicines, the Prophet's instructions regarding divine medicine (the use of prayer and the power of faith for diseases related to psychical conditions), a healthy lifestyle in the style of the Prophet, and a specific explanations of natural ingredients (herbs).

Thibbun nabawi therapist's religiosity is shown by a therapist below:

"Before becoming a thibbun nabawi therapist, I was used to sunnah fasting on Monday and Thursday, reciting Al-Quran, dhuha praying, midnight praying ... During learning to be a thibbun nabawi therapists, we were reminded to fill up our spirituality (ruhiyah), not to let it run dry, so those worships must also be continued. On the graduation exam to become a therapist, I was interviewed and asked about these worship."(Interview with Ratna Nengsih, February $10^{\text {th }}$ 2018).

Aspects of religiosity in health and medicine have been used as research studies in recent decades, both patient's religiosity and therapist. Koenig et al [4] stated that many seriously ill patients use religious beliefs to cope with their illnesses. Koenig stated that there are many studies have now examined the relationship between religious involvement and various aspects of mental health, and also studies about religious involvement and health. The majority of these have found that religious people are physically healthier, lead healthier lifestyles, and require fewer health services. Patients want to be seen and treated as whole persons, not as diseases. A whole person is someone whose being has physical, emotional, and spiritual dimensions. Ignoring any of these aspects of humanity leaves the patient feeling incomplete and may even interfere with healing. For many patients, spirituality is an important part of wholeness, and when addressing psychosocial aspects in medicine, that part of their personhood cannot be ignored [4].

A research by Hillowe [5] was conducted to assess whether clinical judgment is affected by patient religiosity, psycotherapist religiosity, or an interaction between patient and therapist religiosity. The results revealed that, regardless of their own religiosity, all therapists rated religious patients less favorably regarding diagnosis and required sessions. Regardless of the religiosity of the patient, psycotherapists with strong religious beliefs assessed fewer therapy sessions. An interaction was found indicating that nondoctrinally religious therapists had more favorable prognoses for religious patients.

A research by Donohoe et al [6] was objected to characterize the relationship between neonatologists' religiosity or spirituality and the provision of intensive care services for high-risk newborns. The subjects are neonatologists practicing at an American Academy of Pediatrics Neonatal-Perinatal Training Program were surveyed about their religious/spiritual beliefs, provision of LST for critically ill neonates, and communication with families. The results shows that that for the majority of neonatologists participating in this study, differences in critical care practice cannot be attributed to personal religious or spiritual views. These studies contributed to the study of the role of religiosity in the healing process.
However, those researches do not provide examine the religiosity of the therapist in the process of communication with patients. Moreover, the religiosity that are seen are from psychotherapy perspectives and conventional medical science. Meanwhile, the aim of our study is to see how therapists religiosity in the therapeutic communication process from the perspective of Islamic medicine.

Religiosity looks at aspects in the heart of man, so that it is more inherent and intrapersonal in a thibbun nabawi therapist. However, there are dimensions of the therapist's religiosity that are shown in the traditional communication process, namely in the form of verbal and nonverbal communication.

Therapeutic communication is communication carried out by health practitioners (therapists, nurses, doctors, etc.) in helping clients or patients adapt to stress, overcoming psychological disorders in the process of healing patients from their illness [7]. Therapeutic communication that occurs in the process of interpersonal communication between treatment practitioners and their patients / clients is one of the studies in the field of health communication-a scientific subject that is being developed lately in Indonesia. Health communication leads to the process of communication and messages that surround health issues. Knowledge in this field can be categorized based on the emphasis into two major groups, namely the perspective based on the process and perspective based on the message. The process-based approach explores ways in which health meanings are expressed, interpreted, and exchanged, or a process of investigating the interaction and symbolic structuring associated with health. A message-based perspective approach is centered on the formation of effective health messages, as well as on strategic efforts to create effective communication that can achieve the goals of health stakeholders [8].

Therapeutic communication is communication that is consciously planned, purposeful, and its activities are focused on healing patients (Purwanto, 1994). How messages delivered by the therapist in the therapeutic process will also be determined by the therapist's thinking paradigm. The health paradigm in Islamic medicine adheres to a holistic principle that does not separate between psychological health and physical health [9]. The component of holistic health includes spiritual health (sihat ruhiyyat); physical health; psychological and mental health (sihat nafsiyyat), and social health. Spiritual health is maintaining the relationship with God Almighty, which in turn commands relationships with other human beings and the environment. Health in the physical/biological sense is to maintain physiological functions in optimal situations. Psychological and mental health is conscious and peaceful with oneself and the social environment around. Social health means functioning harmoniously in the social environment. Various components of health are closely interrelated with each other.

This holistic principle has consequences for thibbun nabawi therapists. When he/she performs therapeutic communication on a patient, he/she is not only treats the patient from the side of his physical pain, but also tries to 
treat the psychological, spiritual (ruhiyah) aspects, and other aspects depending on the needs and the patient's condition.

"I can usually tell which patients suffer merely from physically ill, and which patients are sick due to their feelings. It can be seen from the eyes, facial expressions.... So, I just listen to their stories. If they need a solution, I will give a solution. If they just want to be listened to, I listen to them until they are done talking. I usually give solutions from Al-Quran ... I also like to ask how their worshipping practices are, then I remind them again about their worship. But yes, I did not force it, I convey it carefully depending on the patient's condition...."(Interview with Ratna Nengsih, 10 February 2018).

This holistic principle will also play a role in how thibbun nabawi's therapists view and practice the dimensions of their religiosity when communicating with patients.

So far, there have been no studies that examine the religiosity of therapists in the process of Islamic medicine. This research will be the start for the next researcher who will study communication in Islamic medicine. This study aims to explore: 1) How is the therapist's religiosity when conducting therapeutic communication in the treatment of thibbun nabawi, and 2) What is the role of therapist's religiosity in the process of therapeutic communication in the treatment of thibbun nabawi.

\section{METHOD}

The research use a qualitative research approach with phenomenological methods. This method is considered the most appropriate because the operationalization of phenomenology is social phenomenology through the concept of intersubjectivity (the meaning of feedback generated in social interaction) and typification, which presupposes the existence of three elements of knowledge that shape human understanding of society, namely the everyday world, social action, and meaning [10].

The approach under the umbrella of phenomenology that is considered appropriate for this research is symbolic interaction. In this study a conceptual framework of symbolic interaction was used to study the therapist's life experience as a respondent.

The source of data in this study comes from verbal and non-verbal expressions (actions) of thibbun nabawi therapists during the therapeutic communication process, plus secondary data obtained from technical worksheets of the informants or from the internet. We use data collection techniques in the form of observation, in-depth interviews and literature studies. We get informants by using snowball sampling technique, which is the process of determining the informant based on the previous informant without defining the amount with certainty by digging up information related to the research topic needed.

Therapist informants are selected in the following criteria:

- Become a thibbun nabawi therapist in a cupping clinic for at least 5 years
- Work at clinic that providing therapeutic services for thibbun nabawi which have official permission from the government of the Republic of Indonesia

- Join and become a member of the thibbun nabawi therapist association which has scientific standards and skills as thibbun nabawi therapist.

- We also interviewed patient as secondary informants.

This research was carried out in cupping clinics in Bandung City, because the most popular type of thibbun nabawi treatment is cupping. The interviews were held in December 2017- July 2018. The informants in this study were as follows:

TABLE 1 RESEARCH INFORMANTS

\begin{tabular}{|c|c|c|}
\hline No & Name & Keterangan \\
\hline 1 & Ian Sopian & $\begin{array}{l}\text { Therapist at the BRC Clinic since } \\
2010 \\
\text { BRC Branch Coordinator } \\
\text { Teaching staff at the cupping } \\
\text { education center owned by BRC. } \\
\text { Member of PBI (Indonesian } \\
\text { Cupping Association) }\end{array}$ \\
\hline 2 & Yayan Taryana & $\begin{array}{l}\text { Therapist at the Buah Batu BRC } \\
\text { Clinic since } 2011 . \\
\text { Member of PBI (Indonesian } \\
\text { Cupping Association). }\end{array}$ \\
\hline 3 & Ratna Nengsih & $\begin{array}{l}\text { Therapists at the BRC Clinic and } \\
\text { at the Cupping Clinic Rumah } \\
\text { Bekam Ujung Berung since } 2007 . \\
\text { Member of PBI (Indonesian } \\
\text { Cupping Association). }\end{array}$ \\
\hline 4 & Sungkana & $\begin{array}{l}\text { Therapist at BRC Clinic J1. } \\
\text { Pajajaran since } 2010 \\
\text { Member of PBI (Indonesian } \\
\text { Cupping Association) }\end{array}$ \\
\hline 5 & Ahmad & BRC Clinic patient \\
\hline 6 & DB & Rumah Bekam patient \\
\hline
\end{tabular}

\section{RESULTS}

\section{A. The Religiosity of Therapists During Therapeutic Communication in the Treatment of Thibbun Nabawi}

The religiosity of the thibbun nabawi therapists is the result of a long process of efforts to establish spirituality, religion understanding, and discipline in performing Islamic religious rituals. Before becoming a thibbun nabawi therapist, they were interested in studying Islam from the age of adolescence, in their 20s, and some were in their 30s (after marriage). Previously, they only practiced religion as a general ritual, such as prayer, fasting, etc., without the desire to explore further. The desire to explore Islam as a comprehensive religious system emerged when interacting with Islamic communities and participating in various religious gathering. Gradually, they tried to practice the knowledge gained from these interactions. They improve the quality and quantity of obligatory worship such as five daily prayers, fasting, and zakat. The five daily prayers completed with the extra prayers, such as prayer before/after the five daily prayer, dhuha prayer, and midnight prayer. Prayers that 
were only done as an obligation, then sought to be more 'solemn'. In addition to carrying out the fast of Ramadan, they also fasted on Monday and Thursday as a extra fasting. Outside of zakat, they also carry out routine donations or alms which are also non obligatory.

Their new understanding of Islam is that Islam is not only about ritual practices according to the pillars of Islam and pillars of faith only. Islam is a broad system of belief that covers the whole aspects of human life which originate in the Al-Quran and Sunnah. Al-Quran as a guideline of life is derived from the words of God Almighty, whereas the Sunnah is all the words and deeds of the Prophet Muhammad that are explained in the hadiths.

The new understanding then brings them to the health sector according to the Islamic perspective. The informants' specific experiences that bring them to 'find' the thibbun nabawi are relatively diverse. Ratna Nengsih, for example, got to know thibbun nabawi when she was looking for Islamic activities for broadening her knowledge of Islam.

"Initially, I just wanted to attend the religious gathering. I was then invited to a gathering by my seniors who had been already a cupping therapist. I did not understand what cupping and thibbun nabawi were. But I was always invited to join her, and so I watched how she did the cupping. Then, I became interested, and finally studied at BRC and graduated as a therapist." (Interview with Ratna Nengsih, February $10^{\text {th }}, 2018$ ).

The previously owned personal religiosity was then strengthened through a coaching system when the therapist became a student at the cupping education center of Bekam Ruqyah Center. The students not only learned how to cup. They also study the laws of Islam, especially that are related to health. The ritual activities were supervised. Students are strongly encouraged to fill in a daily routine ritual control sheet consisting of: five daily prayers, rawatib prayer (before/after the five daily prayers), dhuha prayer, midnight prayer, daily recitation of the Al-Quran and reading the AlMa'tsurat prayers (prayers contained in the Qur'an and exemplified by the Prophet Muhammad). When the students take the graduation exam as cupping therapists held by PBI (Indonesian Cupping Association), they are asked about the discipline of performing routine rituals.

$\mathrm{BRC}$ also has this routine rituals control mechanism for every therapist in branch clinics throughout Indonesia.

"There is a form sheet that must be filled by BRC therapist employees, which are controlled by each branch leader. Filling the form up is not mandatory and does not affect the performance appraisal as a therapist, but it is highly recommended. The choice of mechanism is up to each branch leader." (Interview with Ian Sopian, July $15^{\text {th }}, 2018$ ).

The religiosity of the thibbun nabawi therapist is automatically seen in therapeutic communication while performing cupping therapy to his patients. Based on the results of our interviews and observations, the religiosity includes:

\section{- The belief that God is the only healer.}

Thibbun nabawi therapists, when doing therapeutic communication on patients, must not feel arrogant that he is able to heal. Thibbun nabawi therapists believe that the healer of all diseases is God Almighty, and the therapist is only an ordinary person who endeavors to heal. This affects the choice of verbal messages delivered by the therapist to the patient. Under certain conditions, namely when the patient asks for advice or asks more deeply about the disease or asks for a solution to the therapist, the therapist recommends that the patient get closer to God, because the one who can cure the patient's disease is God only.

\section{- Submission through prayer.}

Before doing the cupping treatment, the thibbun nabawi therapist performed a prayer ritual asking for healing. The prayer is pronounced gently, to the extent that it can be heard by the patient. The intonation and frequency of the pronunciation of the prayer are maintained so as not to disturb the patient, because not all patients are comfortable enough with loud prayer. When praying, the therapist gives his efforts to God's provision for healing. The therapist also sometimes gives special additional prayers that are read in front of the patient if requested by the patient. Some thibbun nabawi therapists used to pray during the previous night prayer, asking God to heal the illness of the patients who will come to the clinic. With this ritual, he/she did not feel burdened, and he/she believe that the patients would be cured by God's permission.

\section{- Inner tranquility while performing theraphy}

Inner tranquility is important to the therapist as he deals with patients with various diseases. The therapist is required to be able to handle the patient in a calm manner, so as to reduce the patient's anxiety about the illness. The inner tranquility of thibbun nabawi therapists is obtained from prayers and routine sunnah rituals carried out before therapy. Prayer which is considered effective in calming the inner therapist is the prayer of Al-Ma'tsurat, while the effective routine sunnah rituals are for example performing the night prayer the previous night, or the dhuha prayer in the morning before starting therapy. The inner tranquility of the therapist can also come from the holy verses of the Al-Quran (murattal) played by audio system at the therapy room the whole time. The inner tranquility of thibbun nabawi therapist when conducting therapeutic communication is seen in therapist nonverbal communication such as regular and unhurried hand movements, friendly facial expressions, low speaking intonation, right speech speed, not too slow nor too fast.

\section{- Desire to get reward and blessings from their patience with patients.}

Patients who come to the clinic have various characters and various problems. Sometimes, the patients come not only complaining of physical illness, but also carries a psychological burden that they wants to share with people they trust. This type of patients is usually female patients who have come to the clinic more than once. Verbally, a therapist who is sensitive 
enough to see the patient's mood, will ask and explore what she feels in a smooth way, without coercion. Nonverbally, the therapist gives subtle touches before doing cupping, for example on the back or on the shoulder. The therapist understands that the patient can simply pour out his heart and not ask for a solution, so he patiently listens to the patient's story even though it is at length. Therapist's patience is also needed when many patients come in one day, while the number of therapists in the clinic is limited. The therapist maintains this patience in the hope that they will receive merit and blessings from God Almighty. In addition to expecting merit, the therapist also wants to benefit others. The therapist believes that when he lightens the burden on others and helps cure diseases, he will be helped by God. In other words, helping others is to help himself too.

\section{- The adherence to Shari'a law}

The adherence of thibbun nabawi therapists to Islamic Shari'a when performing therapeutic communication is seen from the therapist's nonverbal communication in the form of dressing. Islamic Shari'a requires Muslim woman to cover her awrah (the whole body except her face and palms). The Muslim woman therapist of thibbun nabawi wears a veil that covers the chest and loose clothing that is thick/not transparent and loose, in accordance with the guidance of the AlQuran regarding piety clothing for women. Clothing like this was reinforced by the rules of the Indonesian Cupping Association (PBI) as an association where these therapists took shelter. In addition to the way of dressing, the thibbun nabawi therapist verbally and nonverbally regulates that male and female patients are treated in separate rooms, with different therapists. Male patients are treated by male therapists; female patients are handled by female therapists. This is intended so that there is no touch between sexes and their awrah is protected.

\section{- Understanding of treatment methods based on the} hadiths of the Prophet Muhammad.

The therapist has extensive knowledge and understanding about the treatment method of thibbun nabawi, not only about cupping, but also about herbal medicines as well as the lifestyle of the Prophet Muhammad which affected the health and healing of diseases. When explaining about these things, the therapist usually mentions that the knowledge is obtained from the hadiths or verses of the Al-Quran.

\section{- Ability to convey religious messages}

Some thibbun nabawi therapists are able to convey religious messages to their patients if needed, especially to strengthen the patient's mentality when facing his/her illness. Patients in cupping clinics are quite diverse, from minor illnesses such as colds, muscle aches, to cancer and tumors. The diseases most often handled by thibbun nabawi therapists in cupping clinics are diabetes, high blood pressure, cholesterol, and gout.
Religious messages conveyed for example are suggestions to increase sunnah rituals, or seek solutions in the Al-Quran when feeling depressed.. These messages are delivered not in a coercive manner but rather in persuasive manner and often conveyed in the form of stories or simple personal experiences. The quality of delivering religious messages depends on the ability of each therapist. Therapists who have a closed personality tend to be less active in conveying religious messages in a friendly and pleasant way, while therapists with open personalities are the opposite.

\section{B. The Functions of Therapist Religiosity in the Therapeutic Communication Process in the Treatment of Thibbun Nabawi}

The therapist's religiosity delivered through verbal and nonverbal communication to his patients has its own function in the therapeutic communication process. The main goal of therapeutic communication by thibbun nabawi therapists are to help achieving recovery from the ilness, to strengthening the patientss' mental and spiritual condition. Based on the results of our interviews and observations with informants, to achieve these goals, the therapist's religiosity has the following functions:

\section{- Providing comfort for patients}

The majority of Thibun Nabawi patients (95\%) are Muslims. With the same religious background, the therapist's religiosity revealed to patients can be comfortably accepted by patients without resistance. Verbal and nonverbal communication during prayer, providing murattal (reciting of the holy verses of the Al-Quran) through the audio system, patiently listening to 'complaints', and providing friendly solutions and religious messages without coercion, creates comfort for the patient. DB (in the interview February 19, 2018) said, because she was comfortable, she was willing to come repeatedly to handle breast cancer. The same thing was expressed by Ahmad (in an interview on February $\left.18^{\text {th }}, 2018\right)$. Because he was comfortable, he routinely became a cupping patient at the BRC Clinic at least once a month to maintain his body's vitality and prevent his cholesterol from rising. Wet cupping actually includes a small surgery because the patient's skin is slightly injured with a needle, then covered with a cup so that the blood comes out from the surface of the skin. Although it feels a little painful, psychologically the patient still feels comfortable with the treatment because it is helped by the interaction of good communication with the therapist.

\section{- Giving positive suggestions for patients}

The main goal of patients coming to the cupping clinic is to eliminate or cure the disease. Religiosity shown by therapists verbally and nonverbally helps patients grow or strengthen their self-confidence that they can recover. The therapist's religiosity makes the patient calmer and remembers that God is the Healer. According to patients admission, they came routinely to be cupped because they were convinced that there was 
blessing in the form of health, inner and physical wellbeing and reward in undergoing this treatment and trusting his thibbun nabawi therapist. The treatment of thibbun nabawi is a treatment exemplified by the Prophet Muhammad, so that it includes the Sunnah which needs to be followed. By following the Sunnah, they were confident that they will receive a reward and a cure at the same time. In the logic of his faith as a patient, there could not be something exemplified by the Messenger of God without worldly benefits (healing) and the benefits of the afterlife (reward and blessings).

\section{- Increase the credibility of the therapist in the eyes of} the patient

Patients of thibbun nabawi trust the therapist who looks religious. Religious therapists give the impression that their words and actions are more reliable, especially for patients who have believed and understood that cupping is a treatment method that is exemplified by the Prophet Muhammad. The credibility of the therapist has a positive impact on the persuasive power of therapeutic communication in the treatment process. DB for instance, was persuaded to follow the advice of a therapist, whether related to treatment, health care, or related to mental strengthening and mental health of patients in the treatment of cancer.

\section{DISCUSSION}

The symbolic interaction perspective suggests that human behavior must be seen as a process that allows humans to shape and regulate their behavior by considering the expectations of others who are their interaction partners. The definition they give to others, their situation, objects, and even themselves determines their behavior. Their behavior cannot be classified as needs, impulse impulses, cultural demands, or role demands. Humans act only on the basis of their definition or interpretation of objects around them [11].

Religiosity is a packaged concept in the form of a system consisting of dimensions of religious beliefs, religious practices, religious experience, religious knowledge, and religious practice. These five dimensions are interrelated and mutually decisive in shaping one's religiosity [2]. Before conducting therapeutic communication, thibbun nabawi therapists have formed their own religiosity which is the result of previous experiences. They then communicate it in the form of verbal and nonverbal symbols that are adapted to their role as therapists and patient expectations in the relationship of social interaction. From the perspective of symbolic interaction theory, the therapist defines his patients as those who need healing, spiritual reinforcement (ruhiyah) and mental strengthening while undergoing the treatment process in situations of therapeutic communication.

In the perspective of religiosity, the therapist believes that God is a healer, so the therapist positions himself as an 'intermediary'. This is the main belief that forms the basis for subsequent behavior. The therapist's ability is the foundation that makes the next communication actions in the form of cupping action as a therapy considered in accordance with the value of monotheism,
Therapeutic communication is consciously planned and purposeful communication.Its activities are centered for healing patients. Therapeutic communication includes interpersonal communication with the starting point of mutual understanding between nurses / therapists and patients. The fundamental problem in this communication is the mutual need between nurses / therapists and patients, so that it can be categorized into personal communication between nurses / therapists and patients, nurses help, and patients receive assistance [12]. In this process, the thibbun nabawi therapist develops patience in the hope of getting merit and blessings from God Almighty. When he is patient in helping patients, he expects himself to be helped by God in other matters. This is included in the practice of dimension religiosity, because the therapist has practiced the command of God to be patient and help others.

The therapist's religiosity, which includes other dimensions of practice, is when Muslim woman therapists practice God's command to cover their aurah properly according to the Shari'a. Although it does not play a direct role in healing the disease, this physical appearance helps build the credibility of the therapist as a religious Muslim in the eyes of patients.

The therapist's ability to convey religious messages in a 'smooth', friendly, and non-coercive manner, is the practice of the command of God to invite people towards goodness or amar ma'ruf.

Praying, performing night prayers, noon prayers, and AlQuran recitations are ritual dimensions that form the therapist's religiosity. The ritual performed by this therapist is not solely aimed at doing it physically. This ritual is intended to 'fill' the spirit (ruhiyah), with the main aim of gaining inner peace when treating patients.

Therapist understanding of treatment methods based on the hadiths of the Prophet Muhammad included in the dimension of religious religiosity. This understanding is then used as message content in therapeutic communication to patients.

The dimensions of religiosity belonging to the therapist above can provide a psychological effect in the form of comfort in the patient, and give positive suggestions that he can successfully recover from his illness. This positive suggestion for healing is the affective effect of verbal and nonverbal messages delivered by the therapist that God will heal the patient. This suggestion comes from an element of faith in the patient who believes that the treatment of Thibun Nabawi must bring blessings in the world in the form of healing and blessing in the afterlife in the form of reward. A positive suggestion like this can only happen to patients who have faith of any action exemplified or advocated by the Prophet Muhammad.

\section{CONCLUSION}

Therapeutic communication in the treatment of thibbun nabawi is based on the concept of holistic Islamic health, which not only aims to help the cure process of patient's illness, but also mental and spiritual (ruhiyah) strengthening of the patient. Because of this, therapist religiosity plays an important role. This religiosity is inherent in the therapist and is a result of long process in the life of the therapist. This 
religiosity is then seen in verbal and nonverbal messages in the therapeutic communication process.

\section{REFERENCES}

[1] Clayton, Richard R and James W. Gladden. Journal for the Scientific Study of Religion Vol. 13 No. 2. June 1974, pp 134-153.

[2] Jalaluddin. Psikologi Agama. Jakarta: Raja Grafindo, 2016. p 293-294.

[3] Al-Jauziyah, Ibnu Qayyim. Metode Pengobatan Nabi. Translated by Abu Umar Basyer Al-Maidani. Bogor: Griya Ilmu , 2017, p. 15.

[4] Koenig, Harold G. Religion, Spirituality, and Medicine: Application to Clinical Practice. JAMA. October 4, 2000, Vol 284, No. 13, p. 1615 1740

[5] Hillowe, Bruce V.. Effects of Religiosity of Therapist and Patient on Clinical Judgment. Dissertation abstract, 1986.
[6] Donohoe, Pamela, Renee D. Boss, Susan W. Aucott, Elizabeth A. Keene, Paula Teague. The Impact of Neonatologists' Religiosity and Spirituality on Health Care Delivery for High-Risk Neonates, Journal of Palliative Medicine Vol. 13, No. 10.

[7] Suryani. 2006. Komunikasi Terapeutik Teori \& Praktik. Bandung: Alfabeta, 2006, p. 12.

[8] Zoller, Heather M. \& Dutta, M.J.. Emerging Perspectives in Health Communication: Meaning, Culture, and Power. London: Routledge, 2008, p. 13

[9] Kasule, The Concept of Health: An Islamic Perspective. 2008.

[10] Denzin, Norman K., \& Lincoln, Yonna S. Handbook of Qualitative Research. California: Sage Publication, 1994: p 263.

[11] Metodologi Penelitian Kualitatif: Paradigma Baru Ilmu Komunikasi dan Ilmu Sosial lainnya. Bandung: PT Remaja Rosdakarya Offset, 2013, p. 59

[12] Indrawati. Komunikasi Untuk Perawat. Jakarta: EGC, 2003: 48. 